\title{
NEW MACROFUNGIAL RECORD IN HUNGARY: ENTONAEMA CINNABARINUM (COOKE \& MASSEE) LLOYD
}

\section{Gabriella Fintha ${ }^{1 *}$, Lajos Benedek ${ }^{2}$ \& Sándor Orbán1}

${ }^{1}$ Eszterházy Károly University, Institute of Biology, Department of Botany and Plant Physiology, H-3300 Eger, Leányka str. 6, Hungary;

${ }^{2}$ Szent István University, Faculty of Horticultural Sciences, Department of Botany and Soroksár Botanical Garden, H-1118 Budapest, Ménesi str. 44, Hungary; *E-mail: gabriella.fintha@gmail.com

Hungary, Pest County, Ócsa, Selyemrét Nature Trail, on Fraxinus angustifolia subsp. pannonica, leg.: Gabriella Fintha, det.: Lajos Benedek; 47¹6'06”N 19¹3'50"E, (EGR), 05.07.2019.

Entonaema cinnabarinum (Cooke \& Massee) Lloyd is a remarkable fungus in the Xylariaceae (Xylariales, Ascomycota). In spite of its brigthly coloured immature stromata, it is rarely reported from Europe as southern France (Stadler et al. 2004), Bulgaria (Læssoe 1997) and southern Russia (Fedosova 2012). This species has a wide distribution in the world, reported from Africa, Australia, Costa Rica, New Caledonia, Sri Lanka (Rogers 1981), Japan, Philippines (Stadler et al. 2004). E. cinnabarinum was recognized as a tropical species, but recently, we are getting more European data. This species has not been published in Hungary, but one locality was known near Kaposvár, in Tókaj forest park (det.: P. Finy on 07.10.2018.). We report here a new locality found in the swamp forest near Ócsa, on May 2019 (Figure 1). In all cases, we founded specimens on bark of decaying Fraxinus angustifolia subs. pannonica. After finding the first site, we found more than 10 specimens the area, while searching for decaying Fraxinus that characterizes the species' specific habitat (Table 1, Figure 2). On several occasions, we discovered large colonies with specimens of different ages and sizes. We also collected mature and immature stromatas and in late autumn, we collected desiccated specimens as well (det.: G. Fintha on 29.10.2019.). Significant morphological 
differences can be observed between young and old specimens. Young ones have a distinctive appearance with a light reddishyellow or orange color. Stromata of E. cinnabarinum is turgid and resilient when fresh and the colored ectostromata surrounds the perithecia with the liquid-filled cavity, later becoming more reddish brown and darkening and at maturity forms even blackening toward senescence. When liquid is released from stromata, they collapse and start to dry. Dried specimens are similar to Daldinia decipiens, which is a common species in the study area. Entonaema differs from Daldinia by having stromata with a hollow interior and by the perithecia that are arranged in a single layer beneath a thin crust and are easily flattened when being touched (Srutka et al. 2017). In this protected area, the mass occurrence of the species provides an opportunity for the monitoring of morphological changes of this species.

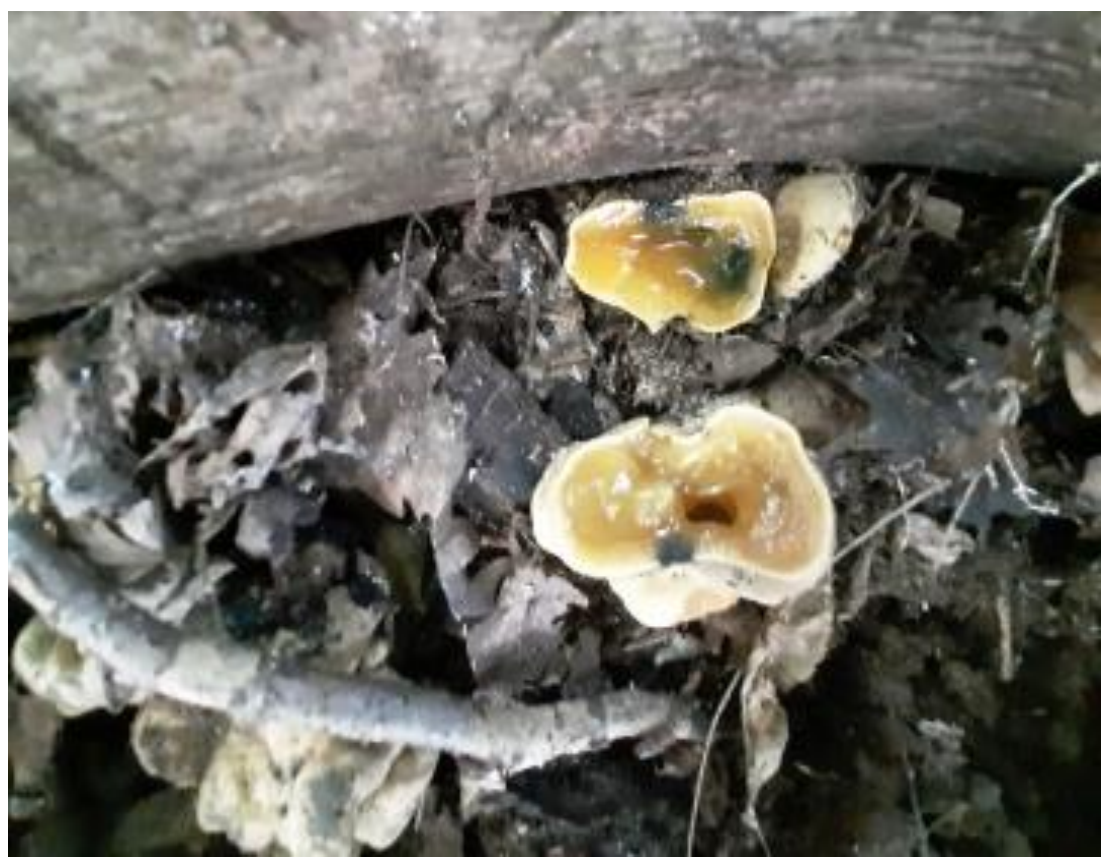

Figure 1. Entonaema cinnabarinum in Selyemrét Nature Trail; $47^{\circ} 15^{\prime} 56^{\prime \prime} \mathrm{N}$ 19¹3'50"E; on bark of decaying Fraxinus angustifolia subs. pannonica (photo: G. Fintha). 
Table 1. The GPS coordinates and substrates data for the sampling points.

\begin{tabular}{ccc}
\hline $\begin{array}{c}\text { number of } \\
\text { sampling site }\end{array}$ & GPS coordinates & substrate \\
\hline $\mathbf{1}$ & $47^{\circ} 16^{\prime} 06^{\prime \prime} \mathrm{N}$ & Fraxinus angustifolia \\
& $19^{\circ} 13^{\prime} 50^{\prime \prime} \mathrm{E}$ & subs. pannonica \\
$\mathbf{2}$ & $47^{\circ} 15^{\prime} 56^{\prime \prime} \mathrm{N}$ & Fraxinus angustifolia \\
& $19^{\circ} 13^{\prime} 50^{\prime \prime} \mathrm{E}$ & subs. pannonica \\
& $47^{\circ} 15^{\prime} 37^{\prime \prime} \mathrm{N}$ & Fraxinus angustifolia \\
$\mathbf{3}$ & $19^{\circ} 14^{\prime} 19^{\prime \prime} \mathrm{E}$ & subs. pannonica \\
& $47^{\circ} 15^{\prime} 29^{\prime \prime} \mathrm{N}$ & Fraxinus angustifolia \\
& $19^{\circ} 15^{\prime} 18^{\prime \prime} \mathrm{E}$ & subs. pannonica \\
4 & $47^{\circ} 15^{\prime} 19^{\prime \prime} \mathrm{N}$ & Fraxinus angustifolia \\
& $19^{\circ} 16^{\prime} 21^{\prime \prime} \mathrm{E}$ & subs. pannonica \\
\hline
\end{tabular}

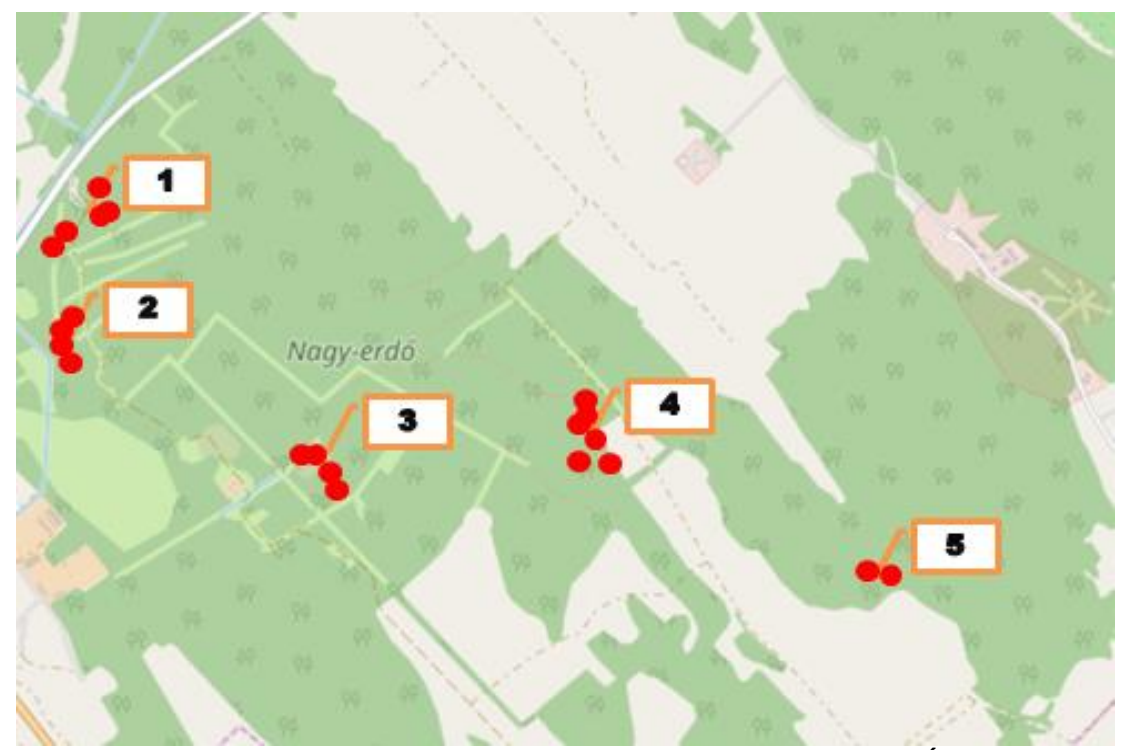

Figure 2. The sampling sites in the investigated area near Ócsa (COpenStreetMap contributors). 


\section{REFERENCES}

Fedosova, A. G. (2012). The new record of Entonaema cinnabarinum (Xylariaceae, Ascomycota) in Europe. Biological Communications 1: 10-13.

LÆSSOE, T. (1997). Entonaema cinnabarina-en eksotisk kernesvamp. Svampe 36: 21-22.

Rogers, J. D. (1981). Sarcoxylon and Entonaema (Xylariaceae), Mycologia 73(1): 28-61. https://doi.org/10.1080/00275514.1981.12021319

ŠRU゚TKa, P., PAŽoutovÁ, S. \& KolaŘíK, M. (2017). Daldinia decipiens and Entonaema cinnabrina as fungal symbionts of Xiphydria wood wasps. Mycological Research 111(2): 224-231. https://doi.org/10.1016/j.mycres.2006.10.006

Stadler, M., Ju, Y.-M. \& Rogers, J.D. (2004). Chemotaxonomy of Entonaema, Rhopalostroma and other Xylariaceae. Mycological Research 108(3): 239-256. https://doi.org/10.1017/S0953756204009347

(submitted: 06.11.2019, accepted: 26.12.2019) 